\title{
Hydrogenophaga defluvii sp. nov. and Hydrogenophaga atypica sp. nov., isolated from activated sludge
}

\author{
Correspondence \\ Peter Kämpfer \\ peter.kaempfer@agrar. \\ uni-giessen.de
}

\author{
Peter Kämpfer, ${ }^{1}$ Renate Schulze, ${ }^{2}$ Udo Jäckel, ${ }^{1}$ Khursheed A. Malik, ${ }^{3}$ \\ Rudolf Amann ${ }^{4}$ and Stefan Spring ${ }^{3}$ \\ ${ }^{1}$ Institut für Angewandte Mikrobiologie, Justus-Liebig-Universität Giessen, 35392 Giessen,
Germany \\ ${ }^{2}$ BRAIN Aktiengesellschaft, 64673 Zwingenberg, Germany \\ ${ }^{3} \mathrm{DSMZ}$ - Deutsche Sammlung von Mikroorganismen und Zellkulturen GmbH, 38124 \\ Braunschweig, Germany \\ ${ }^{4}$ Max-Planck-Institut für Marine Mikrobiologie, Celsiusstraße 1, 28359 Bremen, Germany
}

\begin{abstract}
Two Gram-negative, oxidase-positive rods (strains BSB $9.5^{\top}$ and BSB $41.8^{\top}$ ) isolated from wastewater were studied using a polyphasic approach. 16S rRNA gene sequence comparisons demonstrated that both strains cluster phylogenetically within the family Comamonadaceae: the two strains shared $99.9 \% 16 \mathrm{~S}$ rRNA gene sequence similarity and were most closely related to the type strains of Hydrogenophaga palleronii (98.5\%) and Hydrogenophaga taeniospiralis (98.0\%). The fatty acid patterns and substrate-utilization profiles displayed similarity to the those of the five Hydrogenophaga species with validly published names, although clear differentiating characteristics were also observed. The two strains showed DNA-DNA hybridization values of $51 \%$ with respect to each other. No close similarities to any other Hydrogenophaga species were detected in hybridization experiments with the genomic DNAs. On the basis of these results, two novel Hydrogenophaga species, Hydrogenophaga defluvii sp. nov. and Hydrogenophaga atypica sp. nov. are proposed, with BSB $9.5^{\top}\left(=\mathrm{DSM} 15341^{\top}=\mathrm{CIP} 108119^{\top}\right)$ and BSB $41.8^{\top}$ $\left(=\mathrm{DSM} 15342^{\top}=\right.$ CIP $\left.108118^{\top}\right)$ as the respective type strains.
\end{abstract}

The genus Hydrogenophaga was described by Willems et al. (1989) and, at present, comprises five species: Hydrogenophaga flava, Hydrogenophaga pseudoflava, Hydrogenophaga palleronii, Hydrogenophaga taeniospiralis (Willems et al., 1989) and Hydrogenophaga intermedia (Contzen et al., 2000). Members of this genus are chemo-organotrophic or chemolithoautotrophic, using the oxidation of $\mathrm{H}_{2}$ as an energy source and $\mathrm{CO}_{2}$ as a carbon source, these being major differentiating characteristics for distinguishing between them and other genera of the family Comamonadaceae (Wen et al., 1999; Spring et al., 2004).

Numerous studies applying cultivation-independent methods have revealed that members of the $\beta 1$-group of the Proteobacteria are abundant in activated sludge from wastewater treatment plants (e.g. Amann et al., 1996b; Snaidr et al., 1997). Since members of this group, although

The GenBank/EMBL/DDBJ accession numbers for the 16S rRNA gene sequences of strains BSB $9.5^{\top}$ and BSB $41.8^{\top}$ are AJ585993 and AJ585992, respectively.

Phylogenetic trees and a table showing fatty acid compositions are available as supplementary material in IJSEM Online. closely related, are physiologically diverse, it is almost impossible to infer the metabolic phenotype of members of this group by $16 \mathrm{~S}$ rRNA gene sequence comparison studies. To determine their physiological traits, members of this important bacterial group were isolated, by a directed cultivation procedure, from activated sludge of the wastewater treatment plant München I (Großlappen, Germany) as described by Schulze et al. (1999). The isolates obtained were screened by whole-cell hybridization with specific probes directed against signature regions of $16 \mathrm{~S}$ rRNA sequences. Isolates that hybridized to probe BONE23a (Amann et al., 1996b) directed against members of the $\beta 1$ group of the Proteobacteria were further grouped using the probes LDI (Wagner et al., 1994) and SNA8b (Amann et al., 1996b). Two strains (BSB $9.5^{\mathrm{T}}$ and BSB $41.8^{\mathrm{T}}$ ) that hybridized to probe LDI were also detected by the probe HYD208 directed against members of the genus Hydrogenophaga, which seemed to represent an abundant group of wastewater bacteria (Amann et al., 1996a). Therefore, these two isolates were chosen for further investigation. Both strains were maintained on nutrient agar (Difco). Type strains of all Hydrogenophaga species with validly published names were used for comparison. 
Table 1. Physiological characteristics of the type strains of Hydrogenophaga species

Strains: 1, H. defluvii sp. nov. BSB 9.5 $; 2$, H. atypica sp. nov. BSB 41.8 $; 3$, H. flava DSM 619 $; 4$, H. pseudoflava LMG 5945 $; 5$, H. taeniospiralis DSM $2082^{\mathrm{T}} ; 6, H$. palleronii DSM $63^{\mathrm{T}} ; 7, H$. intermedia $\mathrm{S1}^{\mathrm{T}}$. + , Positive; - , negative; $(+)$, weakly positive. Data for reference taxa are from Contzen et al. (2000).

\begin{tabular}{|c|c|c|c|c|c|c|c|}
\hline Characteristic & 1 & 2 & 3 & 4 & 5 & 6 & 7 \\
\hline \multicolumn{8}{|l|}{ Utilization/assimilation of: ${ }^{*}$} \\
\hline L-Arabinose, sucrose, D-galactose, D-fructose, D-mannose, sorbitol, D-cellobiose & - & - & + & + & - & + & - \\
\hline Mannitol & - & - & + & + & + & - & + \\
\hline Maltose & - & - & + & + & - & - & - \\
\hline L-Histidine & $(+)$ & - & + & + & - & - & - \\
\hline 2-Oxoglutarate & - & + & - & - & - & - & - \\
\hline D-Xylose & - & - & - & + & + & - & - \\
\hline Autotrophic growth with $\mathrm{H}_{2}$ & + & - & + & + & + & + & - \\
\hline Oxidation of thiosulfate to sulfate & - & - & - & - & - & + & + \\
\hline Denitrification $\dagger$ & - & - & - & + & + & - & - \\
\hline Reduction of nitrate & + & + & + & + & + & - & + \\
\hline
\end{tabular}

${ }^{\star}$ Tests (based on a different method) were also performed by Willems et al. (1989) with H. flava, H. pseudoflava, H. taeniospiralis and H. palleronii and gave congruent results.

$\dagger$ For strains BSB 9.5 $5^{\mathrm{T}}$, BSB $41.8^{\mathrm{T}}$ and H. intermedia, no growth was observed under anoxic conditions on $\mathrm{R} 2 \mathrm{~A}$ agar with $\mathrm{NO}_{3}$ as terminal electron acceptor. Data for H. flava, H. pseudoflava, H. taeniospiralis and H. palleronii are from Willems et al. (1989).

Cell morphology was examined by using phase-contrast microscopy (Leitz). Cell dimensions were measured with an ocular $(\times 10)$ and an objective $(\times 100 / 1 \cdot 25)$. Gram-staining was performed by using Hucker's modification (Gerhardt et al., 1994). Colony morphology was studied using a stereo microscope (model SZ 11; Olympus).

The effects of different temperatures on growth were determined on Bacto nutrient agar (Oxoid) incubated at $5,10,28,37,45$ and $50{ }^{\circ} \mathrm{C}$. Physiological tests in microtitre plates were performed as described previously (Kämpfer et al., 1991). Tests were read after 7 days at $30^{\circ} \mathrm{C}$. Chemolithoautotrophic growth of both strains was tested under the conditions described by the DSMZ. Both strains were grown on medium 81 (Malik \& Schlegel, 1981) under an atmosphere of $\mathrm{O}_{2} / \mathrm{CO}_{2} / \mathrm{H}_{2} / \mathrm{N}_{2}$ (approximately $2: 10: 60: 28$, by vol.) (Malik \& Schlegel, 1981). Nitrate reduction and denitrification were tested in R2A broth (Difco) supplemented with $10 \mathrm{mM}$ nitrate under aerobic and anaerobic conditions. The obligately aerobic heterotrophic strains BSB $9.5^{\mathrm{T}}$ and BSB $41.8^{\mathrm{T}}$ grew as circular, entire, slightly convex, smooth, pale-yellow colonies on R2A agar (Oxoid). The cells were Gram-negative, non-spore-forming, motile, rod-shaped organisms. Both strains grew at $28{ }^{\circ} \mathrm{C}$ on nutrient agar, R2A agar and tryptone soy broth agar (Oxoid), but only very weak growth was observed on MacConkey agar (Oxoid). They did not grow on nutrient agar at 5 or $10^{\circ} \mathrm{C}$, but grew well in a temperature range from 20 to $37^{\circ} \mathrm{C}$. Neither strain grew at 40 or $45^{\circ} \mathrm{C}$. Both strains were oxidase- and catalase-positive. Only a few organic compounds could be used as sole sources of carbon (see Table 1 and the species descriptions). Differentiation from all five Hydrogenophaga species is possible on the basis of the results of several tests. Both strains could be differentiated on the basis of the utilization of 2oxoglutarate and L-histidine. A detailed comparison was made with all previously published data (Willems et al., 1989; Contzen et al., 2000). Table 1 shows only those tests for which identical results were obtained with the method used in this study and the method used by Willems et al. (1989). Only strain BSB $9.5^{\mathrm{T}}$ showed good chemolithotrophic growth. Strain BSB $41.8^{\mathrm{T}}$ was not able to grow chemolithoautotrophically under the conditions described - an additional important feature enabling differentiation between the two strains. The utilization of thiosulfate was tested with all type strains of Hydrogenophaga in R2A medium supplemented with $10 \mathrm{mM} \mathrm{Na} \mathrm{Na}_{2} \mathrm{O}_{3} \cdot 5 \mathrm{H}_{2} \mathrm{O}$, as described by Spring et al. (2004). Only the type strains of H. palleronii (DSM $63^{\mathrm{T}}$ ) and H. intermedia (DSM $5680^{\mathrm{T}}$ ) were positive and oxidized thiosulfate to sulfate.

The 16S rRNA gene was analysed as described by Kämpfer et al. (2003). Phylogenetic analysis was performed using the ARB software package (Ludwig et al., 2004) as well as the software package MEGA version 2.1 (Kumar et al., 2001) after multiple alignment of the data by CLUSTAL_X (Thompson et al., 1997). Calculation of distances (with distance options according to the Kimura-2 model) and clustering with the neighbour-joining method and maximum parsimony was performed. Bootstrap values based on 1000 replications were determined to show support for branching points (results are available as supplementary figures in IJSEM 
Online). Nearly complete $16 \mathrm{~S}$ rRNA gene sequences of BSB $9.5^{\mathrm{T}}$ and $\mathrm{BSB} 41.8^{\mathrm{T}}$, respectively comprising 1503 and 1527 nucleotide positions, were determined by PCR amplification and sequencing of the PCR-amplified 16S rRNA genes. A comparative analysis and estimation of the phylogenetic relationships demonstrated that the two strains show $99.9 \%$ sequence similarity and cluster within the genus Hydrogenophaga, being most closely related to $H$. palleronii $(98 \cdot 5 \%)$ and $H$. taeniospiralis $(98 \cdot 0 \%)$.

The $\mathrm{G}+\mathrm{C}$ content was determined by reversed-phase HPLC of nucleosides according to Mesbah et al. (1989).

For fatty acid analysis, cells were grown on YPG agar (Contzen et al., 2000). The fatty acid methyl esters were prepared and analysed as described elsewhere (Kämpfer \& Kroppenstedt, 1996). When grown on YPG agar, the two strains were very similar with regard to their fatty acid patterns and, as with the type strains of all Hydrogenophaga species, contained the fatty acids $15: 0,16: 0$, summed feature $4(16: 1 \omega 7 c$ and/or $15: 0$ iso $2-\mathrm{OH})$ and summed feature $7(18: 1 \omega 7 c, 18: 1 \omega 9 t$ and/or $18: 1 \omega 12 t)$ (see the supplementary table available in IJSEM Online). These fatty acids have also been detected in previous studies and are characteristic of all Hydrogenophaga species with validly published names (Willems et al., 1989). The presence of the hydroxy fatty acid 8:0 3-OH in all Hydrogenophaga species could be confirmed, although this fatty acid could be detected only in trace amounts in H. pseudoflava LMG $5945^{\mathrm{T}}$ and H. taeniospiralis DSM $2082^{\mathrm{T}}$. H. intermedia $\mathrm{S}^{\mathrm{T}}$ (when grown on YPG agar) contained 8: $03-\mathrm{OH}$ in larger amounts $(>2.5 \%)$, a feature shared only by $H$. palleronii DSM $63^{\mathrm{T}}$. Additionally, both isolates (BSB 9.5 and BSB $41.8^{\mathrm{T}}$ ) and the type strains $H$. palleronii DSM $63^{\mathrm{T}}$ and $H$. intermedia $\mathrm{S}^{\mathrm{T}}$ produced large amounts of the cyclopropane fatty acid, 17:0 cyclo, in agreement with data in the literature (Willems et al., 1989).

DNA-DNA hybridization experiments were performed with both isolates and with the type strains of all Hydrogenophaga species by using the method described by Ziemke et al. (1998) except that, for nick translation, $2 \mu \mathrm{g}$ DNA was labelled during a $3 \mathrm{~h}$ incubation at $15^{\circ} \mathrm{C}$. Strains BSB $9.5^{\mathrm{T}}$ and BSB $41.8^{\mathrm{T}}$ showed a DNA-DNA hybridization value of $51 \%$ (mean value from four experiments, including reciprocal analyses), indicating that they belong to different species, despite their close 16S rRNA gene sequence similarity. The following DNA-DNA hybridization values between BSB $9.5^{\mathrm{T}}$ and other Hydrogenophaga type strains were found: H. flava, $30 \%$; $\mathrm{H}$. pseudoflava, $26 \%$; H. palleronii, $29 \%$; H. taeniospiralis, $13 \%$; H. intermedia, $12 \%$. The DNA-DNA hybridization values between BSB $41.8^{\mathrm{T}}$ and other Hydrogenophaga type strains were as follows: $H$. flava, $32 \%$; $H$. pseudoflava, $28 \%$; $H$. palleronii, $31 \%$; H. taeniospiralis, $26 \%$; H. intermedia, $9 \%$.

Although both strains showed a very high degree of $16 \mathrm{~S}$ rRNA gene sequence similarity, they could be differentiated from each other and from other species of the genus
Hydrogenophaga by means of DNA-DNA hybridization and a few physiological tests. In conclusion, we propose the names Hydrogenophaga defluvii sp. nov. for strain BSB 9.5 and Hydrogenophaga atypica sp. nov. for strain BSB $41.8^{\mathrm{T}}$.

\section{Description of Hydrogenophaga defluvii sp. nov.}

Hydrogenophaga defluvii (de.flu'vi.i. L. n. defluvium sewage; L. gen. n. defluvii of sewage).

Cells are Gram-negative, rod-shaped, motile and $1.5 \mu \mathrm{m}$ long by $0.5 \mu \mathrm{m}$ wide, with rounded ends. Metabolism is oxidative. Oxidase-positive. Able to grow chemolithoautotrophically on $\mathrm{H}_{2}$ under the conditions described. Chemolithoautotrophic growth of $H$. defluvii (in contrast to that of $H$. flava) is not inhibited by high levels of oxygen in the atmosphere ( $5 \% \mathrm{O}_{2}$ or more). Thiosulfate is not oxidized to sulfate. The fatty acid pattern is characterized by the presence of the fatty acids typical of the genus Hydrogenophaga, as well as the hydroxylated fatty acid 8:0 3-OH and also small amounts of 9:03-OH. Phylogenetically, the species is a member of the genus Hydrogenophaga. On YPG agar at $25^{\circ} \mathrm{C}$, colonies are circular, entire, slightly convex, smooth and pale yellow. Growth occurs at $37^{\circ} \mathrm{C}$ but not at $10^{\circ} \mathrm{C}$. Only a few organic compounds can be used as sole sources of carbon: gluconate, glutarate, lactate, 3hydroxybutyrate, pyruvate, suberate, L-alanine, L-leucine, L-aspartate, L-histidine, phenylalanine, L-proline, 3-hydroxybenzoate and 4-hydroxybenzoate. Furthermore, tests for hydrolysis of L-alanine $p$-nitroanilide (pNA) are positive. Does not utilize $N$-acetyl-D-glucosamine, L-arabinose, arbutin, D-cellobiose, D-fructose, D-galactose, D-glucose, D-mannose, D-mannitol, adipate, D-melibiose, L-rhamnose, ribose, sucrose, salicin, trehalose, D-xylose, adonitol, inositol, sorbitol, putrescine, acetate, propionate, cisaconitate, trans-aconitate, 4 -aminobutyrate, azelate, citrate, fumarate, glutarate, itaconate, D-malate, mesaconate, 2oxoglutarate, $\beta$-alanine, L-ornithine, L-serine, $\mathrm{L}$-tryptophan or phenylacetate as sole sources of carbon. Tests for hydrolysis of $p$-nitrophenyl (pNP) $\alpha$-D-glucopyranoside, pNP $\beta$-D-glucopyranoside, pNP $\beta$-D-galactopyranoside, pNP $\beta$-D-glucuronide, pNP phenylphosphonate, pNP phosphorylcholine, 2-deoxythymidine- $5^{\prime}$-pNP phosphate, glutamate- $\gamma$-3-carboxy pNP-ester and L-proline pNA are negative. The $\mathrm{G}+\mathrm{C}$ content of the genomic DNA is $65 \mathrm{~mol} \%$. Characteristics used for differentiation from other Hydrogenophaga species are given in Table 1.

The type strain, BSB $9.5^{\mathrm{T}}\left(=\mathrm{DSM} 15341^{\mathrm{T}}=\mathrm{CIP} 108119^{\mathrm{T}}\right)$, was isolated from activated sludge in Munich, Germany.

\section{Description of Hydrogenophaga atypica sp. nov.}

Hydrogenophaga atypica (Gr. pref. a-, an- not; L. adj. typicus, -a, -um from Gr. adj. tupikos typical; N.L. fem. adj. atypica atypical).

Cells are Gram-negative, rod-shaped, motile and $1.5 \mu \mathrm{m}$ long by $0.5 \mu \mathrm{m}$ wide, with rounded ends. Oxidative metabolism. Oxidase-positive. Unable to grow chemolithoautotrophically 
on $\mathrm{H}_{2}$ under the conditions described. Thiosulfate is not oxidized to sulfate. The fatty acid pattern is characterized by the presence of the fatty acids typical of the genus Hydrogenophaga with the hydroxylated fatty acid $8: 0$ 3-OH and also 9:0 3-OH. Phylogenetically, the species is a member of the genus Hydrogenophaga. On YPG agar at $25^{\circ} \mathrm{C}$, colonies are circular, entire, slightly convex, smooth and pale yellow. Growth occurs at $37^{\circ} \mathrm{C}$ but not at $10^{\circ} \mathrm{C}$. Only a few organic compounds can be used as sole sources of carbon: gluconate, glutarate, lactate, 3-hydroxybutyrate, 2-oxoglutarate, pyruvate, phenylalanine, L-proline, 3hydroxybenzoate and 4-hydroxybenzoate. Furthermore, tests for hydrolysis of L-alanine pNA are positive. Does not utilize $N$-acetyl-D-glucosamine, L-arabinose, arbutin, D-cellobiose, D-fructose, D-galactose, D-glucose, Dmannose, D-mannitol, adipate, D-melibiose, L-rhamnose, ribose, sucrose, salicin, trehalose, D-xylose, adonitol, inositol, sorbitol, putrescine, acetate, propionate, cisaconitate, trans-aconitate, suberate, 4-aminobutyrate, azelate, citrate, fumarate, glutarate, itaconate, D-malate, mesaconate, L-alanine, $\beta$-alanine, L-leucine, L-aspartate, L-histidine, L-ornithine, L-serine, L-tryptophan or phenylacetate as sole sources of carbon. Tests for hydrolysis of pNP $\alpha$-D-glucopyranoside, pNP $\beta$-D-glucopyranoside, pNP $\beta$-D-galactopyranoside, $\mathrm{pNP} \beta$-D-glucuronide, $\mathrm{pNP}$ phenylphosphonate, pNP phosphorylcholine, 2-deoxythymidine- $5^{\prime}$-pNP phosphate, glutamate- $\gamma$-3-carboxy pNP-ester and L-proline pNA are negative. The G+C content of the genomic DNA is $64 \mathrm{~mol} \%$. Characteristics used for differentiation from the other Hydrogenophaga species are given in Table 1.

The type strain, BSB $41.8^{\mathrm{T}}\left(=\mathrm{DSM} 15342^{\mathrm{T}}=\right.$ CIP $\left.108118^{\mathrm{T}}\right)$, was isolated from activated sludge in Munich, Germany.

\section{Acknowledgements}

We thank Jean Euzéby for his nomenclatural advice and Peter Schumann for determining the $\mathrm{G}+\mathrm{C}$ values.

\section{References}

Amann, R., Ludwig, W., Schulze, R., Spring, S., Moore, E. \& Schleifer, K. H. (1996a). rRNA-targeted oligonucleotide probes for the identification of genuine and former pseudomonads. Syst Appl Microbiol 19, 501-509.

Amann, R., Snaidr, J., Wagner, M., Ludwig, W. \& Schleifer, K. H. (1996b). In situ visualization of high genetic diversity in a natural bacterial community. J Bacteriol 178, 3496-3500.

Contzen, M., Moore, E. R. B., Blümel, S., Stolz, A. \& Kämpfer, P. (2000). Hydrogenophaga intermedia sp. nov., a 4-aminobenzenesulfonate degrading organism. Syst Appl Microbiol 23, 487-493.

Gerhardt, P., Murray, R. G. E., Wood, W. A. \& Krieg, N. R. (editors) (1994). Methods for General and Molecular Bacteriology. Washington, DC: American Society for Microbiology.
Kämpfer, P. \& Kroppenstedt, R. M. (1996). Numerical analysis of fatty acid patterns of coryneform bacteria and related taxa. Can J Microbiol 42, 989-1005.

Kämpfer, P., Steiof, M. \& Dott, W. (1991). Microbiological characterisation of a fuel-oil contaminated site including numerical identification of heterotrophic water and soil bacteria. Microb Ecol 21, 227-251.

Kämpfer, P., Dreyer, U., Neef, A., Dott, W. \& Busse, H.-J. (2003). Chryseobacterium defluvii sp. nov., isolated from wastewater. Int J Syst Evol Microbiol 53, 93-97.

Kumar, S., Tamura, K., Jakobsen, I. B. \& Nei, M. (2001). MEGA2: Molecular Evolutionary Genetics Analysis software. Bioinformatics 17, 1244-1245.

Ludwig, W., Strunk, O., Westram, R. \& 29 other authors (2004). ARB: a software environment for sequence data. Nucleic Acids Res 32, 1363-1371.

Malik, K. A. \& Schlegel, H. G. (1981). Chemolithoautotrophic growth of bacteria able to grow under $\mathrm{N}_{2}$-fixing conditions. FEMS Microbiol Lett 11, 63-67.

Mesbah, M., Premachandran, U. \& Whitman, W. B. (1989). Precise measurement of the $\mathrm{G}+\mathrm{C}$ content of deoxyribonucleic acid by high-performance liquid chromatography. Int J Syst Bacteriol 39, 159-167.

Schulze, R., Spring, S., Amann, R., Huber, I., Ludwig, W., Schleifer, K.-H. \& Kämpfer, P. (1999). Genotypic diversity of Acidovorax strains isolated from activated sludge and description of Acidovorax defluvii sp. nov. Syst Appl Microbiol 22, 205-214.

Snaidr, J., Amann, R., Huber, I., Ludwig, W. \& Schleifer, K. H. (1997). Phylogenetic analysis and in situ identification of bacteria in activated sludge. Appl Environ Microbiol 63, 2884-2896.

Spring, S., Jäckel, U., Wagner, M. \& Kämpfer, P. (2004). Ottowia thiooxydans gen. nov., sp. nov., a novel facultatively anaerobic, $\mathrm{N}_{2} \mathrm{O}-$ producing bacterium isolated from activated sludge, and transfer of Aquaspirillum gracile to Hylemonella gracilis gen. nov., comb. nov. Int J Syst Evol Microbiol 54, 99-106.

Thompson, J. D., Gibson, T. J., Plewniak, F., Jeanmougin, F. \& Higgins, D. G. (1997). The CLUSTAL_X windows interface: flexible strategies for multiple sequence alignment aided by quality analysis tools. Nucleic Acids Res 25, 4876-4882.

Wagner, M., Amann, R., Kämpfer, P., Assmus, B., Hartmann, A., Hutzler, P., Springer, N. \& Schleifer, K. H. (1994). Identification and in situ detection of gram-negative filamentous bacteria in activated sludge. Syst Appl Microbiol 17, 405-417.

Wen, A., Fegan, M., Hayward, C., Chakraborty, S. \& Sly, L. I. (1999). Phylogenetic relationships among members of the Comamonadaceae, and description of Delftia acidovorans (den Dooren de Jong 1926 and Tamaoka et al. 1987) gen. nov., comb. nov. Int J Syst Bacteriol 49, 567-576.

Willems, A., Busse, J., Goor, M. \& 8 other authors (1989). Hydrogenophaga, a new genus of hydrogen-oxidizing bacteria that includes Hydrogenophaga flava comb. nov. (formerly Pseudomonas flava), Hydrogenophaga palleronii comb. nov. (formerly Pseudomonas palleronii), Hydrogenophaga pseudoflava comb. nov. (formerly Pseudomonas pseudoflava and "Pseudomonas carboxydoflava"), and Hydrogenophaga taeniospiralis comb. nov. (formerly Pseudomonas taeniospiralis). Int J Syst Bacteriol 39, 319-333.

Ziemke, F., Höfle, M. G., Lalucat, J. \& Rosselló-Mora, R. (1998). Reclassification of Shewanella putrefaciens Owen's genomic group II as Shewanella baltica sp. nov. Int J Syst Bacteriol 48, 179-186. 